\title{
Exploring Patterns of Offending by Juvenile Offenders in Australia: What Is the Evidence for a Specialist Violent Offender?
}

\author{
Andrew McGrath ${ }^{1}$
}

Received: 23 December 2014 / Revised: 5 August 2015 / Accepted: 18 August 2015 /

Published online: 28 August 2015

(C) Springer International Publishing AG 2015

\begin{abstract}
The question of whether there are offenders who specialise in violent offences is one that has been of considerable interest to life course developmental criminology as well as policy makers and the public. The current study investigated this using an administrative dataset of juvenile offenders from New South Wales, Australia. Specifically, it asked whether offenders convicted of a serious violent offence differed in their demographic, criminal history and reoffending profiles and whether there were further differences in these factors across gender and cultural identity. Overall, the findings indicated that violence is more likely to occur in the context of an extensive criminal career. Indigenous male individuals were the most frequent and chronic offenders in the sample. The policy and theoretical implications of these findings are discussed.
\end{abstract}

Keywords Violence $\cdot$ Specialization $\cdot$ Juvenile Offending

\section{Introduction}

The investigation of serious violent offending careers has been a matter of longstanding interest to criminological researchers and policy makers. The question of whether there are individuals who specialise in committing these types of offences has been of particular concern, both from the perspective of refining rehabilitative programs as well as incapacitating dangerous offenders. Inquiry into the different dimensions of criminal careers has increased markedly since the publication of the seminal report of the National Academy of Science in 1986 [5]. These inquiries have evolved into the distinctive theoretical perspective of life course developmental

Andrew McGrath

amcgrath@csu.edu.au

1 School of Psychology, Charles Sturt University, Panorama Avenue, Bathurst, NSW, Australia 
criminology. Life course criminology examines crime as it unfolds across the lifespan, focussing on phenomena such as the initiation, frequency and continuation of offending behaviour. It assumes these changes follow in an ordered developmental sequence [5, 42]. An extensive international research literature examining these questions has since emerged [13].

A number of different parameters of the criminal career identified by Blumstein and colleagues have been the subject of empirical attention, especially the onset and frequency of offending behaviour [e.g. 7, 35, 38]. The nature of criminal offending across the lifespan, and in particular the question of whether offenders specialise in certain offence types or are versatile, has also been a subject of investigation. Although the extant evidence favours the conclusion that offenders are generalists, rather than specialists, it is yet to be settled whether this pattern holds across all criminal careers [13]. In relation to violent offending, the major research question addressed by life course criminology is whether certain offenders' criminal careers comprise of exclusively violent offences [43]. The current study will address this question by investigating patterns of offending behaviour in a sample of juvenile offenders sentenced in the New South Wales (NSW, Australia) Children's Court in 2007 and 2008. Specifically, it will ask whether there is evidence to suggest the existence of an exclusively violent group of offenders or whether offending versatility best characterises the criminal careers of juvenile offenders in Australia.

\section{The Developmental Life Course Perspective on Violent Offending}

A considerable body of research has been conducted to investigate both the antecedents of violence and the characteristics of the violent offender from the perspective of life course criminology [43]. This research shows the following: (1) violent offences comprise only a small proportion of the total number of offences committed in the course of a criminal career $[41,47,52]$, (2) there is limited evidence to suggest the existence of a group of exclusively violent offenders [4, 8, 51, 53], (3) overall recidivism rates for violent offences tend to be low [40, 41], (4) violent offending careers tend to be shorter $[15,16,45]$, and (5) violent offenders are difficult to distinguish from frequent offenders using well-recognised risk factors for offending [18].

Much of the evidence pertaining to violent offending careers is derived from wellknown longitudinal studies. In the USA, the National Youth Survey, the Philadelphia birth cohorts and the groundbreaking Boston study of Eleanor and Sheldon Glueck have proven to be particularly rich sources of evidence [14, 24, 57]. Internationally, the Cambridge study of juvenile delinquency and the Dunedin birth cohort have also provided an important theoretical and empirical foundation for developmental criminology [17, 37].

There is also a growing body of research from other international jurisdictions examining life course criminology in general and the examination of violent offending careers in particular. For instance, Blokland et al. [4] used a sample of 5164 offenders from the Netherlands to test whether distinct lifespan offending trajectories could be identified. They found evidence to suggest the existence of four groups: sporadic offenders, low-rate desisters, moderate-rate desisters and high-rate persisters. However, they found little evidence that these groups differed in the proportion of 
violent offences committed. If anything, the high frequency offenders seemed to specialise in property offences (p. 936). In Australia, Mazerolle et al. [35] examined differences between individuals whose first conviction was for a violent offence and those for whom it was non-violent, using a dataset of 1503 juvenile offenders from the Queensland Youth Justice Criminal Trajectories Project (YJCTP). The initially violent offenders were more likely to subsequently engage in serious criminal activity and also have more proven juvenile offences; however, in other respects, their subsequent criminal careers were less serious. They were less likely to be sentenced to juvenile detention, and they had fewer adult orders and offences, a shorter overall offending career and fewer convictions for violent offences in adulthood.

\section{Offence Specialisation and Versatility}

The question of whether there are individuals who exclusively commit violent offences is one that remains important for both criminological theory and public policy. Many would judge this type of offender to be an attractive target for incapacitative policies. Therapeutic programs may also benefit from the identification of such a group of offenders. The more general question of whether offenders tend to specialise in one type of offence or are by contrast versatile in their offending patterns is one that has been the subject of a large number of studies from the life course developmental perspective [e.g. 25, 26, 36]. A comprehensive review that considered this question concluded 'the preponderance of offenders, and by preponderance we mean virtually all offenders, are generalists' [13].

A further research question that has received some attention is whether this finding holds across gender. A study using data from the 1958 Philadelphia birth cohort found some evidence to suggest that males were more likely to specialise than females, although females were more likely to specialise in status offences [29]. Farrington and colleagues found persistent female offenders were overall more likely to specialise, although the males were more likely to specialise in violent offences. Like the study of Kempf, female specialisation was particularly evident in so-called status offences, in this case, running away [19]. Mazerolle et al. [34] also used data from the 1958 Philadelphia cohort to investigate the relationship between the onset of criminal offending, specialisation and gender. They observed offenders with an earlier age of onset to be more versatile than individuals with a later onset. Although males were substantially more likely to engage in life course offending, they observed little evidence to suggest that there were substantial gender differences in versatility among those offenders (both male and female) who were criminally active across the observation period. In a more recent study from the Netherlands using data from the Criminal Career and Life Course Study [44], women were found to be more likely to commit property offences than men, but the proportion of violent offences across criminal careers was far higher for men than women. Finally, in a study using data from the 1503 serious juvenile offenders in the YJCPT, Fitzgerald et al. [23] found that although there was broad concurrence between the types of offences committed by male and female offenders, more males could be classified as serious violent/versatile offenders, whereas more females were classified as less-serious low-level violent offenders.

An additional demographic characteristic particularly salient to the Australian criminal justice system is Indigenous status. The original inhabitants of Australia, while 
comprising just $2.5 \%$ of the total population, are heavily over-represented at all levels of the criminal justice system. This over-representation is particularly evident in the juvenile justice system of NSW, where approximately half of all individuals in detention are Indigenous [39]. While reasons for this over-representation are contested, it has been suggested that high levels of Indigenous violence are at least in part responsible for the disparity [54]. Life course criminology research in Australia has found Indigenous Australians to be more likely to be frequent and chronic offenders [9, 20]. For instance, Broidy et al. [9], in a study of 41,280 offenders born in 1983/1984 in Queensland, Australia, found Indigenous males to have the highest lifetime rates of offending, with only $16.4 \%$ of this cohort having no contact with the criminal justice system up to the age of 25 . The equivalent figure for non-Indigenous females was $84.5 \%$. Both Indigenous males and females were over-represented in the chronic offending groups, and while overall Indigenous males represented the most serious and chronic group of offenders, some evidence was observed to suggest that Indigenous female offending was more akin to the non-Indigenous males than females. These results suggest the intersections between gender and Indigenous status in criminal offending careers in Australia are a subject worthy of further investigation.

\section{The Current Study}

While the characterisation of most offending careers as versatile rather than specialist is generally accepted, the question of whether this characterisation holds in all circumstances and jurisdictions is less settled. In particular, as much of the extant evidence is derived from the USA and other international jurisdictions, research examining the question of violent offence specialisation in Australia can potentially add to our knowledge of the developmental progression of criminal careers in this country, as well as providing evidence for how well the predominantly American research findings generalise to international jurisdictions. Further, the recent findings of Broidy et al. [9] suggest that there is a considerable amount to be learned from examining intersections between sex and Indigenous status in the development of criminal careers. To date, this relationship has not been examined in regard to offending specialisation in Australia. The current study will therefore add to this literature by examining a sample of juvenile offenders in NSW, Australia. It will first aim to investigate the characteristics of juveniles convicted of a violent offence and, second, explore patterns of reoffending by these individuals. The specific research questions asked are as follows: (1) what are the characteristics of juveniles convicted of a violent offence, and do these characteristics differ according to gender and Indigenous status and (2) does the commission of a violent offence raise the likelihood of a further violent offence, and does this differ according to gender and Indigenous status?

\section{Method}

\section{Data}

Data for this study were obtained from the NSW Bureau of Crime Statistics and Research's reoffending database. This contains the records of all individuals sentenced 
in a NSW court since 1994. Further information regarding the matching procedures used and their accuracy can be found in Hua and Fitzgerald [27] and Weatherburn et al. [55]. The current dataset consists of all finalised Children's Court appearances between 2007 and 2008 where a juvenile was convicted of one or more charges. In what follows, this will be referred to as the index appearance. The dataset also consists of information relating to the next offence for which the young person was convicted, as well as their offending prior to the index appearance. The data is best thought of as a 'snapshot' rather than complete record of each offender's criminal career.

In the original dataset, age ranged from 10 to 35 . Because the current study focuses on juvenile offenders, individuals whose age was over 21 at the time of sentence were dropped from subsequent analyses. ${ }^{1}$ There were also a number of individuals whose Indigenous status and age of first court appearance were unknown. These observations were also dropped from the analyses leaving a final sample of 7501.

As the current dataset is derived from official records, the only variables that could be included in the analyses were those recorded routinely by the justice agencies responsible for dealing with young offenders. Nevertheless, a number of well-known factors related to both violent and general offending were available for analysis. The measure of recidivism utilised is also derived from official records. There has been a longstanding debate in criminology relating to the validity and reliability of official records of offending as opposed to self-reports. This was addressed by Huizinga and Elliott [28] using data from the National Youth Survey. The advantage of this dataset was that delinquency was measured initially using annual face-to-face interviews. These data were able to be compared to a later search of police records. While it is clear that officially detected offending represents only a subset of total offending behaviour, Huizinger and Elliott did detect some problems with self-reported offending. Specifically, they found evidence to suggest that trivial offences were over-reported by participants and more serious offences under-reported. Although no self-reported measure of offending was available in the current study, reliance on official records is defensible given these findings, particularly in a study of serious violent offending.

\section{Measures}

\section{Violent Offence}

In the current study, the definition of violence will be based on the Australian Standard Offence Classification [3]. This classification divides offences into 16 divisions ranging from homicide to assorted miscellaneous offences. Divisions 1 to 6 involve the infliction of some kind of harm to the victim. Within each division, offences are broken down further so that it is possible to distinguish between aggravated and common assault. Arriving at a suitable definition of violence involves balancing considerations of harm and seriousness. Ideally, trivial offences that result in no bodily harm will be excluded, while incidents that cause significant psychological harm will be included. The current study will follow the approach taken in the report of the Office of Juvenile Justice and Delinquency Prevention's Study Group on Serious Violent Juvenile Offenders [31]. Here, a violent offender was

\footnotetext{
${ }^{1}$ It is possible for individuals over the age of 18 to be dealt with by the Children's Court, if, for example, they were later arrested for an offence committed while under age.
} 
defined as a person who had committed one or more of the following offences: homicide, aggravated assault, robbery, kidnapping, sexual assault and arson [32]. In the current study, a violent offence will therefore be defined as one of the following: homicide, serious assault (regardless of whether an injury is sustained by the victim), sexual assault, abduction and kidnapping and robbery. From this, it follows that a violent offender will be defined as an individual convicted of one of these offences. Just under $20 \%$ of the sample was convicted of a violent offence $(N=1496)$ as their index offence in the study period 2007-2008.

\section{Reoffending}

A reoffence was defined as the next offence, either juvenile or adult, that resulted in a conviction by a court, that was committed after the index offence in the 2007/2008 study period. Analyses were based on the actual date of reoffence rather than reconviction. The maximum observation time for reoffending was 3 years from the end of $2008 .^{2}$ Reoffending will be measured two ways: first, whether the young person committed a further violent or non-violent offence in the follow-up period and, second, the time this took to occur following the index court appearance. The definition of a violent reoffence was consistent with the definition of a violent offence. Some $8.9 \%$ of the sample $(N=$ $666)$ had a violent offence as their first reoffence. A non-violent reoffence was defined as any other offence leading to a conviction. Some 5127 of the sample $(68.35 \%)$ were observed to reoffend non-violently in the follow-up period, with a total reoffending rate of $77.25 \%$ across the sample. Free time to first reoffence varied from zero to 1096 days $(M=543.84, \mathrm{SD}=422.46)$. The observation period for reoffending dates from the time of conviction and excludes time spent in custody. Specifically, data from the relevant justice institutions relating to admissions and discharges from custody were obtained by BOCSAR to the nearest day (i.e. if a person was admitted at $6.00 \mathrm{a} . \mathrm{m}$. and discharged at 1.00 p.m., this would be counted as 1 day in custody). This time in days was subtracted from the total observation period, meaning that the measure of reoffending used was uncontaminated by time spent in custody.

\section{Demographic Information}

Information relating to sex, Indigenous status, age at current and first conviction, socioeconomic disadvantage and remoteness at the time of sentence was available (see Table 1 for more information in this regard).

\section{Previous and Current Criminal Information}

A number of measures of current and past offending were available. Prior offending variables included a raw count of previous convictions, as well as more detailed information relating to previous sentences incurred and offence types committed.

\footnotetext{
${ }^{2}$ A reviewer correctly pointed out this means that people convicted at the start of the 2007/2008 study period would have a longer period under observation than those convicted towards the end of this period. Given that the mean time to reoffence was approximately 18 months and the maximum time just over 3 years, this would bias the results reported here. In any event, the multivariate analyses conducted (i.e. Cox regression) specifically adjust for unequal observation periods.
} 
Table 1 Descriptive statistics, complete sample $(N=7501)$

\begin{tabular}{|c|c|c|}
\hline Variable & Total & Description \\
\hline Violent offence & $1496(19.9 \%)$ & $\begin{array}{l}\text { A conviction for a violent offence in the current } \\
2007 / 2008 \text { dataset }\end{array}$ \\
\hline Gender (male) & $6147(81.95 \%)$ & \\
\hline Age & $M=16.22(\mathrm{SD}=1.62)$ & Age at conviction in the current dataset \\
\hline Age at first offence & $M=15.36(\mathrm{SD}=1.72)$ & Age of first conviction \\
\hline Indigenous status & $2682(35.76 \%)$ & $\begin{array}{l}\text { This variable indicates if the young person has ever } \\
\text { identified as Indigenous }\end{array}$ \\
\hline Previous convictions & $M=1.64(\mathrm{SD}=2.73)$ & $\begin{array}{l}\text { This variable indicates if the individual had been } \\
\text { previously convicted in the New South Wales } \\
\text { Children's Court. The range observed } \\
\text { was from } 0 \text { to } 29 \text {. }\end{array}$ \\
\hline Prior prison & $610(8.13 \%)$ & $\begin{array}{l}\text { This variable indicates if the individual had ever } \\
\text { received a full-time custodial sentence. }\end{array}$ \\
\hline Prior suspended sentence & $382(5.09 \%)$ & $\begin{array}{l}\text { The relevant juvenile is sentenced to a control order; } \\
\text { however, this is suspended. Any further } \\
\text { offence can lead to the immediate application } \\
\text { of the control order. }\end{array}$ \\
\hline Prior violence & $2264(30.18 \%)$ & $\begin{array}{l}\text { This indicates whether the young person had a } \\
\text { previous conviction for a violent offence. }\end{array}$ \\
\hline Prior breach of justice order & $860(11.47 \%)$ & $\begin{array}{l}\text { This includes offences such as breach of bail } \\
\text { or suspended sentence. }\end{array}$ \\
\hline Prior juvenile contact & $4098(54.63 \%)$ & $\begin{array}{l}\text { This measures prior contact with the juvenile } \\
\text { justice system, including both court and } \\
\text { restorative justice contacts. }\end{array}$ \\
\hline Counts & $M=1.14(\mathrm{SD}=0.88)$ & $\begin{array}{l}\text { The number of counts of the principle offence } \\
\text { at the time of sentencing. The range was } 1-38\end{array}$ \\
\hline Concurrent offences & $M=1.61(\mathrm{SD}=2.40)$ & $\begin{array}{l}\text { The number of concurrent charges (both proven } \\
\text { and unproven and excluding the principle } \\
\text { offence) at sentence. The range was } 0-44 \text {. }\end{array}$ \\
\hline Remoteness index & $M=1.86(\mathrm{SD}=1.04)$ & $\begin{array}{l}\text { Remoteness was measured using postcode-level } \\
\text { data derived from the Australian standard } \\
\text { geographical classification tool [3]. There } \\
\text { are five categories in this variable: } 1=\text { living } \\
\text { in a major city }(N=3813,50.8 \%), 2=\text { living } \\
\text { in inner regional areas }(N=1529,20.4 \%), 3= \\
\text { living in outer regional areas }(N=1724,23 \%) \text {, } \\
4=\text { living in remote areas }(N=241,3.2 \%) \text { and } \\
5=\text { living in very remote areas }(N=194,2.6 \%) \text {. }\end{array}$ \\
\hline Socio-economic disadvantage & $M=2.55(\mathrm{SD}=1.03)$ & $\begin{array}{l}\text { This is measured using postcode-level data derived } \\
\text { from the socio-economic indexes for areas tool } \\
\text { (SEIFA) [2]. } \\
\text { It was recoded into quartiles where } 1=\text { very } \\
\text { low disadvantage }(N=1458,19.4 \%), 2=\text { low } \\
\text { disadvantage }(N=2017,27 \%), 3= \\
\text { disadvantaged }(N=2436,32.5 \%) \text { and } 4= \\
\text { high disadvantage }(N=1590,21.2 \%)\end{array}$ \\
\hline
\end{tabular}

Information relating to the current offending profile was also available. Table 1 has full details in this regard 


\section{Results}

\section{Descriptive Statistics}

Analyses were conducted using Stata version 11 [49]. Table 1 describes the variables used in the study together with the relevant characteristics of the sample. Males accounted for $81.95 \%(N=6147)$ and Indigenous people $35.76 \%(N=2682)$ of the current sample. Age at current conviction was approximately 16, whereas age at first conviction was about a year younger. Over a half of the individuals in the study had previous contact with juvenile justice agencies. Prior convictions also varied considerably across the sample, from none to over 20 . The median number of prior convictions was 1 .

Table 2 shows more detailed information relating to the offending careers of the study sample. Overall, just under a half $(47.4 \%)$ of the total sample had no prior convictions, and just under $2 \%$ had over 10 . To explore differences by gender and Indigenous status, a categorical variable was constructed indicating whether the individual was a non-Indigenous female $(N=810,10.8 \%)$, a non-Indigenous male $(N=$ $4009,53.5 \%)$, an Indigenous female $(N=544,7.2 \%)$ and an Indigenous male $(N=$ $2138,28.5 \%$ ). Indigenous males had comparatively more prior convictions than the other groups. Only $35 \%$ of the Indigenous males had no previous convictions, compared to $45 \%$ of the Indigenous females, $51 \%$ of the non-Indigenous males and $63 \%$ of the non-Indigenous females. By contrast, $4.2 \%$ of the Indigenous males had more than ten previous convictions, over double the rate of the full sample (1.9\%). The Indigenous females fell somewhere between the Indigenous and non-Indigenous males, being over-represented in the groups with two or more previous convictions. The nonIndigenous females overall had the fewest prior convictions.

Table 3 shows the mean ages of the individuals in each prior offending category. The overall pattern was that the individuals appearing in court for the first time were youngest $(M=15.85)$, while the frequent offenders were oldest $(M=17.84)$. While there were differences depending on gender and Indigenous status, the differences were in practice modest, with effect sizes ranging from 0.03 to 0.09 . The tendency was for the Indigenous individuals in each category to be younger than the non-Indigenous individuals. $^{3}$

\section{Research Question 1: What Are the Characteristics of Juveniles Convicted of a Violent Offence, and Do These Characteristics Differ According to Gender and Indigenous Status?}

Table 4 shows differences between offenders convicted of a violent and non-violent offence in the 2007/2008 study period. The young people convicted of a violent offence were slightly older than their non-violent counterparts and were older when their first conviction was recorded. They were more likely to be non-Indigenous; however, there

\footnotetext{
${ }^{3}$ Some readers might be concerned about the use of parametric tests with skewed data. Although some of the variables were skewed, the large sample makes it likely that the assumption of normality for sampling distributions was satisfied [22]. Further, Lumley et al. [33] demonstrated the validity of $t$ tests in extremely non-normal data using a number of simulations.
} 
Table 2 Offending careers: prior convictions by gender and Indigenous status: percent $(N)$

\begin{tabular}{llllll}
\hline $\begin{array}{l}\text { Prior } \\
\text { convictions }\end{array}$ & $\begin{array}{l}\text { Non-Indigenous } \\
\text { females }(N=810)\end{array}$ & $\begin{array}{l}\text { Non-Indigenous } \\
\text { males }(N=4009)\end{array}$ & $\begin{array}{l}\text { Indigenous } \\
\text { females }(N=544)\end{array}$ & $\begin{array}{l}\text { Indigenous males } \\
(N=2138)\end{array}$ & $\begin{array}{l}\text { Total } \\
(N=7501)\end{array}$ \\
\hline 0 & $62.8(509)$ & $51.1(2047)$ & $45(245)$ & $35.2(753)$ & $47.4(3554)$ \\
1 & $20(162)$ & $21.7(869)$ & $20.4(111)$ & $17.7(378)$ & $30.2(1520)$ \\
2 & $8.15(66)$ & $10.4(416)$ & $13.1(71)$ & $11.5(246)$ & $10.7(799)$ \\
3 to 4 & $5.7(46)$ & $9.8(393)$ & $11.8(64)$ & $14.8(317)$ & $10.9(820)$ \\
5 to 10 & $2.7(24)$ & $6.2(247)$ & $7.7(42)$ & $16.6(355)$ & $8.9(668)$ \\
Greater than 10 & $0.4(3)$ & $0.9(37)$ & $2(11)$ & $4.2(89)$ & $1.9(140)$ \\
Total & $10.8(810)$ & $53.5(4009)$ & $7(544)$ & $28.5(2138)$ & $100(7501)$ \\
\hline
\end{tabular}

$X^{2}=493.78, P=0.001, V=0.15$

was no difference in gender observed (males accounted for $82.2 \%$ of the violent offenders and $81.9 \%$ of the non-violent offenders). The violent offenders had, in general, a less-extensive criminal history: they had fewer previous convictions and were less likely to have previously been incarcerated (both actual and suspended control orders), breached a justice order or had contact with juvenile justice agencies. They were also charged with fewer counts of the index offence and had fewer concurrent offences. The violent offenders, however, were more likely to have had a previous history of violence. They were also more likely to come from a non-remote area of the state. The differences observed were modest, with effect sizes ranging from nil to small. The biggest effect sizes observed were for the remoteness index $(d=0.26)$ and age at first conviction $(d=0.16)$. Overall, the profile of the individuals convicted of a violent offence indicates a later onset of offending, less-extensive criminal history with the exception of previous violence and a less-serious offending profile. They were also more likely to reside in an urban area.

A further comparison was made between a group of juveniles who had a conviction prior to the 2007/2008 study period for violence, whose current offence was violent and whose next subsequent offence was also violent. In other words, these were offenders

Table 3 Offending careers: prior convictions and age by gender and Indigenous status: mean (SD)

\begin{tabular}{llllllll}
\hline $\begin{array}{l}\text { Prior } \\
\text { convictions }\end{array}$ & $\begin{array}{l}\text { Non-Indigenous } \\
\text { females } \\
(N=810)\end{array}$ & $\begin{array}{l}\text { Non-Indigenous } \\
\text { males } \\
(N=4009)\end{array}$ & $\begin{array}{l}\text { Indigenous } \\
\text { females } \\
(N=544)\end{array}$ & $\begin{array}{l}\text { Indigenous } \\
\text { males } \\
(N=2138)\end{array}$ & $\begin{array}{l}\text { Total } \\
(N=7501)\end{array}$ & $P$ value $^{\mathrm{a}}$ & Eta \\
\hline 0 & $15.76(1.42)$ & $16.14(1.41)$ & $15.39(1.63)$ & $15.30(1.80)$ & $15.85(1.56)$ & $<0.001$ & 0.05 \\
1 & $16.41(1.39)$ & $16.55(1.32)$ & $16(1.65)$ & $15.85(1.67)$ & $16.32(1.48)$ & $<0.001$ & 0.04 \\
2 & $16.21(1.32)$ & $16.90(1.24)$ & $16.18(1.66)$ & $15.82(1.93)$ & $16.45(1.60)$ & $<0.001$ & 0.09 \\
3 to 4 & $17(1.40)$ & $17.02(1.40)$ & $16.39(1.45)$ & $16.44(1.70)$ & $16.74(1.55)$ & $<0.001$ & 0.04 \\
5 to 10 & $16.88(1.42)$ & $17.51(1.52)$ & $16.79(1.28)$ & $16.92(1.55)$ & $17.13(1.54)$ & $<0.001$ & 0.04 \\
Greater than 10 & $17.33(0.58)$ & $18.60(1.64)$ & $17.55(1.63)$ & $17.58(1.60)$ & $17.84(1.60)$ & .009 & 0.08 \\
Total & $16.04(1.45)$ & $16.50(1.45)$ & $15.88(1.67)$ & $16(1.85)$ & $16.56(1.62)$ & $<0.001$ & 0.03 \\
\hline
\end{tabular}

${ }^{a}$ Group differences were tested using a one-way ANOVA 
Table 4 Descriptive statistics: offenders convicted of a violent and non-violent offence in the 2007/2008 study period

\begin{tabular}{lllll}
\hline Variable & Violent $(N=1496)$ & Non-violent $(N=6005)$ & $P$ value & Effect size \\
\hline Gender (male) & $1230(82.2 \%)$ & $4917(81.9 \%)$ & 0.761 & $<0.01$ \\
Age & $16.32(\mathrm{SD}=1.44)$ & $16.24(\mathrm{SD}=1.66)$ & 0.028 & 0.04 \\
Age at first offence & $15.63(\mathrm{SD}=1.57)$ & $15.28(\mathrm{SD}=1.76)$ & 0.001 & 0.16 \\
Indigenous status & $432(29 \%)$ & $2250(37.4 \%)$ & 0.001 & 0.07 \\
Previous convictions & $1.28(\mathrm{SD}=2.34)$ & $1.73(\mathrm{SD}=2.82)$ & 0.001 & 0.13 \\
Prior prison & $89(5.95 \%)$ & $521(8.68 \%)$ & 0.001 & 0.04 \\
Prior suspended sentence & $43(2.87 \%)$ & $339(5.65 \%)$ & 0.001 & 0.05 \\
Prior violence & $534(35.70 \%)$ & $1730(28.81 \%)$ & 0.001 & 0.06 \\
Prior breach of justice order & $123(8.22 \%)$ & $737(12.27 \%)$ & 0.001 & 0.05 \\
Prior juvenile contact & $743(49.67 \%)$ & $3355(55.87 \%)$ & 0.001 & 0.05 \\
Counts & $1.10(\mathrm{SD}=0.46)$ & $1.15(\mathrm{SD}=0.95)$ & 0.003 & 0.04 \\
Concurrent offences & $1.49(\mathrm{SD}=2.16)$ & $1.64(\mathrm{SD}=2.46)$ & 0.011 & 0.05 \\
Remoteness index & $1.59(\mathrm{SD}=0.93)$ & $1.93(\mathrm{SD}=1.05)$ & 0.001 & 0.26 \\
Socio-economic disadvantage & $2.54(\mathrm{SD}=1.06)$ & $2.56(\mathrm{SD}=1.02)$ & 0.299 & 0.01 \\
\hline
\end{tabular}

For the categorical variables, differences were tested using $X^{2}$ and $t$ tests were used to compare means of the continuous variables

for whom there was evidence for at least three separate convictions for a violent offence. There were only a small number of offenders in the current dataset who fit these criteria $(N=69,0.92 \%)$. Table 5 shows descriptive statistics for this group of young people. The comparison group is those young people who have prior, current and future convictions for non-violent offences only ( $N=1369,18 \%$ of total dataset). Statistics for each of the prior criminal history variables are shown with the exception of prior violence.

When these two groups were compared, no differences were observed in relation to age, gender or Indigenous status. The persistently violent offenders were more likely to come from an urban as opposed to regional area $(d=0.19)$. They also had more prior offences $(d=0.20)$, more prior breach offences ( $p h i=0.05$ ) and more prior involvement with juvenile justice agencies ( $p h i=0.07)$. Although the non-violent group had a slightly older age of first court appearance, this difference was not significant.

Table 6 displays descriptive statistics for the individuals convicted of a violent offence in the 2007/2008 period, broken down by gender and Indigenous status. The Indigenous offenders, and in particular the Indigenous males, had a far more serious criminal profile than the other groups. Age of onset for the Indigenous males and females was approximately equivalent (15.08 and 15.03 , respectively) and somewhat younger than the nonIndigenous males and females (15.93 and 15.53). ${ }^{4}$ The Indigenous males had considerably more prior convictions (2.27 compared to the overall mean of 1.28 ). They were also more

\footnotetext{
${ }^{4}$ Note the relevant legislation in NSW holds court to be the last option for dealing with juvenile offending. A court appearance is the culmination of a process that takes the young person through cautions, official warnings, and youth justice conferences. This age of onset is unlikely therefore to represent the young person's first contact with justice agencies.
} 
Table 5 Descriptive statistics, 'persistently' violent offenders compared to non-violent offenders

\begin{tabular}{|c|c|c|c|c|}
\hline & $\begin{array}{l}\text { Non-violent } \\
(N=1369)\end{array}$ & $\begin{array}{l}\text { Persistently violent } \\
\text { offender }(N=69)\end{array}$ & $P$ value & Effect size \\
\hline Indigenous status & $\begin{array}{l}556 \\
\quad(40.6 \%)\end{array}$ & $26(37.7 \%)$ & 0.628 & 0.01 \\
\hline Gender (male) & $1369(86 \%)$ & $58(84 \%)$ & 0.617 & 0.01 \\
\hline Age & $16.46(1.58)$ & $16.49(1.13)$ & 0.450 & $<0.01$ \\
\hline Socio-economic disadvantage & $2.47(1.00)$ & $2.58(1.16)$ & 0.181 & 0.05 \\
\hline Remoteness index & $2.02(1.05)$ & $1.54(0.87)$ & 0.001 & 0.19 \\
\hline Prior conviction & $2.14(1.83)$ & $3.03(2.86)$ & 0.001 & 0.20 \\
\hline Age at first offence & $15.13(1.71)$ & $14.88(1.75)$ & 0.112 & 0.06 \\
\hline Prior imprisonment & $110(8.0 \%)$ & $9(13 \%)$ & 0.141 & 0.04 \\
\hline Prior suspended sentence & $73(5.30 \%)$ & $6(8.7 \%)$ & 0.232 & 0.03 \\
\hline Prior breach offence & $\begin{array}{l}179 \\
\quad(13.1 \%)\end{array}$ & $15(21.7 \%)$ & 0.040 & 0.05 \\
\hline Prior juvenile offence & $1245(91 \%)$ & $69(100 \%)$ & 0.009 & 0.07 \\
\hline
\end{tabular}

For the categorical variables, differences were tested using $X^{2}$ and $t$ tests were used to compare means of the continuous variables

likely to have been previously imprisoned ( $16.3 \%$ compared to an overall rate of $5.95 \%$ ). The next most imprisoned group was the Indigenous females $(7.5 \%)$ followed by the nonIndigenous males $(2.8 \%)$ and the non-Indigenous females (only two of these individuals had previous experience of detention). The effect size for this difference could be

Table 6 Descriptive statistics, offenders convicted of a violent offence in the 2007/2008 study period by gender and Indigenous status, mean (SD) and $N(\%)$

\begin{tabular}{llllllll}
\hline & $\begin{array}{l}\text { Non- } \\
\text { Indigenous } \\
\text { females } \\
(N=172)\end{array}$ & $\begin{array}{l}\text { Non- } \\
\text { Indigenous } \\
\text { males } \\
(N=892)\end{array}$ & $\begin{array}{l}\text { Indigenous } \\
\text { females } \\
(N=94)\end{array}$ & $\begin{array}{l}\text { Indigenous } \\
\text { males } \\
(N=338)\end{array}$ & $\begin{array}{l}\text { Total } \\
(N=1496)\end{array}$ & $\begin{array}{c}P \text { value } \\
\text { Effect } \\
\text { size }^{\mathrm{a}}\end{array}$ \\
\hline Age & $15.87(1.40)$ & $16.48(1.33)$ & $15.82(1.47)$ & $16.29(1.64)$ & $16.32(1.44)$ & $<0.001$ & 0.03 \\
Age at first offence & $15.53(1.34)$ & $15.93(1.38)$ & $15.03(1.64)$ & $15.08(1.90)$ & $15.63(1.60)$ & $<0.001$ & 0.06 \\
Previous conviction & $0.61(1.08)$ & $1.01(1.84)$ & $1.46(2.30)$ & $2.27(2.34)$ & $1.28(2.34)$ & $<0.001$ & 0.06 \\
Prior prison & $2(1.2 \%)$ & $25(2.8 \%)$ & $7(7.5 \%)$ & $55(16.3 \%)$ & $89(5.95 \%)$ & $<0.001$ & 0.24 \\
Prior suspended & $1(0.6 \%)$ & $16(1.8 \%)$ & $3(3.2 \%)$ & $23(6.8 \%)$ & $43(2.9 \%)$ & $<0.001$ & 0.14 \\
$\quad$ sentence & $48(27.9 \%)$ & $292(32.7 \%)$ & $42(44.7 \%)$ & $152(44.8 \%)$ & $534(35.7 \%)$ & $<0.001$ & 0.13 \\
Prior violence & $10(5.8 \%)$ & $53(5.9 \%)$ & $11(11.7 \%)$ & $49(14.5 \%)$ & $123(8.2 \%)$ & $<0.001$ & 0.12 \\
Prior breach of justice \\
$\quad$ order
\end{tabular}

\footnotetext{
${ }^{a}$ For continuous variables, a one-way ANOVA was performed, the relevant effect size is eta squared, for categorical variables $X^{2}$, and the relevant effect size reported is Cramer's $V$
} 
considered large (Cramer's $V=0.24)$. This general pattern was observed for the other indices of prior offending although the Indigenous males and females exhibited similar rates of prior violence ( $44 \%$ compared to the overall rate of $35.7 \%$ ).

\section{Research Question 2: Does the Commission of a Violent Offence Raise the Likelihood of a Further Violent Offence? Does This Differ According to Gender and Indigenous Status?}

\section{Reoffending: Bivariate Analyses}

Table 7 shows the proportion of offenders reconvicted of a violent and non-violent offence in the follow-up period. The statistics are broken down by gender and Indigenous status. Of the 6055 individuals who were initially convicted of non-violent offence, some $4268(70.5 \%)$ were reconvicted for a further non-violent offence in the follow-up period, while $500(8 \%)$ had a violent offence as their next conviction. Indigenous males were over-represented in both categories, and non-Indigenous females under-represented. For instance, while Indigenous males make up some $28 \%$ of the sample, $36 \%$ of these individuals are reoffending violently in the follow-up period. The respective figures for non-Indigenous females were 10.8 and $6.8 \%$.

Turning to the 1496 individuals whose index offence was violent, 859 (57\%) reoffended non-violently, and $166(11 \%)$ reoffended violently. These findings show a tendency for violence to be repeated; however, the effect size could best be described as small $\left(X^{2}=103.22\right.$, $P<0.001, V=0.12)$. No strong difference emerged by gender and Indigenous status although the non-Indigenous males were marginally more likely to commit both types of reoffences.

Table 8 shows free (i.e. excluding time spent in custody) time to the next reoffence for those convicted of a violent and non-violent offence. The general pattern is that the violent offenders took considerably longer to reoffend, regardless of whether the next offence was violent or non-violent.

Examining differences by gender and Indigenous status, the most noteworthy finding is that Indigenous males were markedly quicker to commit their next reoffence, regardless of the offence type that they were initially and subsequently convicted of (Table 8). For instance, where their initial offence was violent, they took only 223 days on average to commit a further violent offence, compared to 416 for the Indigenous females, 468 for the non-Indigenous males and 491 for the non-Indigenous females. This general pattern was observed in all offending categories.

Finally, it might be recalled that the definition of violence used in this study included only serious violent offences (i.e. homicide, assault causing injury, sexual assault and robbery). As one further way of exploring patterns of violence in the sample, the proportion of individuals reconvicted of such an offence was compared to those reconvicted of any offence causing injury. ${ }^{5}$ These data are shown in Table 9. Indigenous males were again over-represented in both groups; however, Indigenous females were also considerably over-represented in the group reconvicted for any type of assault. While they made up only $7.3 \%$ of the sample, they comprised over $12 \%$ of the individuals who committed these types of offences in the follow-

\footnotetext{
${ }^{5}$ ASOC subdivision 2, acts intended to cause injury, defined as 'acts, excluding attempted murder and those resulting in death (Division 01), which are intended to cause non-fatal injury or harm to another person and where there is no sexual or acquisitive element' [3]
} 
Table 7 Reoffending by gender and Indigenous status, $N(\%)$

Initial offence violent $(N=1496)$

\begin{tabular}{llllll}
\cline { 5 - 6 } \cline { 5 - 6 } & $\begin{array}{l}\text { General } \\
\text { recidivism } \\
(N=859)^{\mathrm{a}}\end{array}$ & $\begin{array}{l}\text { Violent } \\
\text { recidivism } \\
(N=166)^{\mathrm{b}}\end{array}$ & & $\begin{array}{l}\text { General } \\
\text { recidivism } \\
(N=4268)^{\mathrm{c}}\end{array}$ & $\begin{array}{l}\text { Violent } \\
\text { recidivism } \\
(N=500)^{\mathrm{d}}\end{array}$ \\
\hline Non-Indigenous females $(N=810,10.8 \%)$ & $68(7.9 \%)$ & $15(9 \%)$ & & $325(7.6 \%)$ & $34(6.8 \%)$ \\
Non-Indigenous males $(N=4009,53.5 \%)$ & $485(56.5 \%)$ & $100(60.2 \%)$ & $2177(51 \%)$ & $242(48.4 \%)$ \\
Indigenous females $(N=544,7.3 \%)$ & $58(6.8 \%)$ & $14(8.4 \%)$ & & $313(7.3 \%)$ & $44(8.8 \%)$ \\
Indigenous males $(N=2138,28.5 \%)$ & $248(28.9 \%)$ & $37(22.3 \%)$ & & $1453(34 \%)$ & $180(36 \%)$
\end{tabular}

Initial offence non-violent $(N=6005)$

${ }^{\mathrm{a}} X^{2}=61.78, P<0.001, V=0.20$

${ }^{\mathrm{b}} X^{2}=2.37, P=0.498, V=0.04$

${ }^{\mathrm{c}} X^{2}=210.10, P<0.001, V=0.19$

${ }^{\mathrm{d}} X^{2}=16.65, P=0.001, V=0.05$

up period. Put another way, some $23 \%$ of all Indigenous females in the study were reconvicted for any kind of assault in the observation period. So, while there was no strong tendency for Indigenous females to commit a further serious violent offence, when the criteria were relaxed to include all type of assault, they were found to be considerably overrepresented.

\section{Reoffending: Multivariate Analyses}

To further explore patterns of reoffending in the sample, a number of Cox regression models were run using the full sample $(N=7501){ }^{6}$ As the major aim of these analyses is

\footnotetext{
${ }^{6}$ Multivariate analyses in this study were based on survival analysis, which is a method of statistical analysis used in epidemiological and medical research. In survival analysis, the outcome measure of interest is the period of time until a particular event occurs, which often in medical research is the death of a patient (hence 'survival' analysis). Data of interest in survival analysis are as follows. Start is the date observation commenced or the date of entry to the study. In the current study, this is the date of the index court proceedings in 2007/2008. Stop is the closing date of observation, indicating either the closure of the study (i.e. 3 years after the end of the 2007/2008 study period or December 2011) or the date of the next reoffence resulting in a conviction. Recidivism status $(d)$ is zero if the participant has not reoffended in the period of observation and is one if there is an offence in the observation period. Therefore, $d$ is a dichotomous variable indicating reoffence status during the period that the participant is under observation. Total observation time $(T)$ equals stop minus start where $d=0$ and date of reoffence minus start where $d=1$. The participants' data can be used to construct a survival curve for the entire group. Theoretically, this is a smooth curve where the probability of survival at the start of the study $(t=0)$ is 1 and at the end of the study (hypothetically where $t=\infty$ ) is 0 . In practice, it takes the form of a step function. As previously mentioned, this survival time specifically excludes time spent in custody.

The impact of a number of covariates on the survival function can be assessed using the Cox proportional hazards model. This allows the researcher to determine the impact of one independent variable on the dependent variable, while holding the other independent variables constant, thus identifying possibly spurious bivariate relationships. The statistic of interest is the hazard ratio, which is a measure of the effect of each variable in the model, adjusted for the other variables. Interpreting a hazard ratio is similar to interpreting a risk ratio in epidemiological research. A hazard ratio of 1 means that the independent variable exerts no effect on the dependent variable, whereas a hazard ratio of 5 means that each extra unit of the independent variable that the participant obtains makes them five times more likely to fail (i.e. reoffend). Conversely, a hazard ratio of 0.2 means that each unit of the independent variable that they score makes them five times less likely to fail.
} 
Table 8 Free time to first reoffence by gender and Indigenous status, mean days (SD)

\begin{tabular}{|c|c|c|c|c|}
\hline & \multicolumn{2}{|c|}{ Initial offence violent } & \multicolumn{2}{|c|}{ Initial offence non-violent } \\
\hline & $\begin{array}{l}\text { General } \\
\text { recidivism }^{\mathrm{a}}\end{array}$ & $\begin{array}{l}\text { Violent } \\
\text { recidivism }^{\mathrm{b}}\end{array}$ & $\begin{array}{l}\text { General } \\
\text { recidivism }^{c}\end{array}$ & $\begin{array}{l}\text { Violent } \\
\text { recidivism }^{\mathrm{d}}\end{array}$ \\
\hline Non-Indigenous females & $495.54(375.18)$ & $491.13(404.81)$ & $482.68(380.39)$ & $350.53(361.22)$ \\
\hline Non-Indigenous males & $486.50(345.20)$ & 468.85 (336.76) & $393.07(341.80)$ & $349.46(312.69)$ \\
\hline Indigenous females & $430.07(404.60)$ & $416.86(451.73)$ & $393.74(362.44)$ & $348.32(303.85)$ \\
\hline Indigenous males & $301.90(294.93)$ & $223.35(174.05)$ & $289.20(293)$ & $264.53(273.48)$ \\
\hline Total & $430.11(347.9)$ & $411.76(339.33)$ & $364.58(335.94)$ & $318.86(303.81)$ \\
\hline
\end{tabular}

${ }^{\mathrm{a}} F=17.20, P<0.001$

${ }^{\mathrm{b}} F=5.42, P=0.001$

${ }^{\mathrm{c}} F=45.13, P<0.001$

${ }^{\mathrm{d}} F=3.03, P=0.028$

to test the impact of previous violence on future violence, the main independent variable of interest was whether a conviction for a violent offence had been recorded in the $2007 / 2008$ study period. In the first model, the dependent variable was a violent reoffence. This was run for the full sample and then separately for males and females. The other demographic and criminal history/profile variables were included in the model as controls. The same procedure was repeated with general recidivism as the dependent variable. The main aim of these analyses was to determine whether being convicted for a violent offence raised the likelihood of a further violent offence. No evidence of multicollinearity was observed in any of the models, with VIFs ranging from 1 to $4.70(M=2.05)$ for the violent recidivism model and 1 to $4.98(M=1.99)$ for the general recidivism model. The proportional hazards assumption (that hazard ratios are constant over time) was violated for the general recidivism model $\left(X^{2}=42.08\right.$, $P<0.001)$. To further investigate this, the Kaplan-Meier observed survival curves were plotted with the Cox predicted curves for each variable in the model [48]. As all curves were both parallel and adjacent, it was determined that the violation was relatively minor and the model should be run unchanged. No such violation was observed for the violent recidivism model.

Table 10 shows the results for the violent recidivism model. The most noteworthy finding was that a violent offence was unrelated to violent recidivism for either the full

Table 9 Reoffence type, by gender and Indigenous status, $N(\%)$

\begin{tabular}{lll}
\hline & Serious violence $(N=666)^{\mathrm{a}}$ & Any assault $(N=1041)^{\mathrm{b}}$ \\
\hline Non-Indigenous females $(N=810,10.8 \%)$ & $49(7.4 \%)$ & $118(11.3 \%)$ \\
Non-Indigenous males $(N=4009,53.5 \%)$ & $342(51.6 \%)$ & $479(46 \%)$ \\
Indigenous females $(N=544,7.3 \%)$ & $58(8.7 \%)$ & $129(12.4 \%)$ \\
Indigenous males $(N=2138,28.5 \%)$ & $217(32.6 \%)$ & $315(30.3 \%)$ \\
\hline
\end{tabular}

${ }^{\mathrm{a}} X^{2}=15.02, P=0.002, V=0.05$

${ }^{\mathrm{b}} X^{2}=58.15, P<0.001, V=0.09$ 
Table 10 Predictors of violent recidivism, full sample, females and males

\begin{tabular}{|c|c|c|c|c|c|c|}
\hline & \multicolumn{6}{|l|}{ Violent recidivism } \\
\hline & \multicolumn{2}{|l|}{ Full sample ${ }^{\mathrm{a}}$} & \multicolumn{2}{|l|}{ Females $^{\mathrm{b}}$} & \multicolumn{2}{|l|}{ Males $^{\mathrm{c}}$} \\
\hline & $H$ & $P$ & $H$ & $P$ & $H$ & $P$ \\
\hline Violent offence & $1.14(0.95,1.37)$ & 0.157 & $1.38(0.89,2.14)$ & 0.156 & $1.09(0.89,1.33)$ & 0.390 \\
\hline Indigenous status & $1.73(1.45,2.06)$ & 0.001 & $2.37(1.57,3.57)$ & 0.000 & $1.62(1.33,1.97)$ & 0.000 \\
\hline Gender & $1.38(1.12,1.71)$ & 0.003 & & & & \\
\hline Age at conviction & $0.92(0.85,1.01)$ & 0.075 & $0.65(0.48,0.88)$ & 0.005 & $0.96(0.88,1.06)$ & 0.422 \\
\hline Age at first offence & $1.03(0.95,1.13)$ & 0.440 & $1.33(0.98,1.79)$ & 0.064 & $1.01(0.92,1.10)$ & 0.817 \\
\hline Socio-economic disadvantage & $0.95(0.89,1.03)$ & 0.222 & $1.08(0.89,1.31)$ & 0.418 & $0.93(0.86,1.00)$ & 0.065 \\
\hline Remoteness & $0.84(0.77,0.91)$ & 0.001 & $0.86(0.71,1.05)$ & 0.147 & $0.84(0.76,0.92)$ & 0.000 \\
\hline Prior offences & $1.25(1.12,1.40)$ & 0.001 & $1.47(1.07,2.04)$ & 0.018 & $1.22(1.08,1.38)$ & 0.001 \\
\hline Prior prison & $1.40(1.03,1.90)$ & 0.034 & $0.77(0.16,3.77)$ & 0.742 & $1.43(1.04,1.97)$ & 0.028 \\
\hline Prior suspended sentence & $0.99(0.69,1.42)$ & 0.953 & $0.59(0.07,5.10)$ & 0.634 & $1.00(0.70,1.44)$ & 0.992 \\
\hline Prior violence & $1.31(1.05,1.63)$ & 0.018 & $1.29(0.70,2.38)$ & 0.416 & $1.30(1.03,1.65)$ & 0.029 \\
\hline Prior breach of justice order & $1.02(0.78,1.33)$ & 0.876 & $0.62(0.26,1.48)$ & 0.278 & $1.10(0.83,1.46)$ & 0.515 \\
\hline Prior juvenile contact & $0.97(0.76,1.23)$ & 0.790 & $1.05(0.58,1.91)$ & 0.872 & $0.97(0.75,1.26)$ & 0.833 \\
\hline Counts & $0.91(0.78,1.07)$ & 0.264 & $0.91(0.63,1.31)$ & 0.606 & $0.91(0.76,1.09)$ & 0.298 \\
\hline Concurrent offences & $1.02(0.99,1.05)$ & 0.129 & $1.04(0.95,1.15)$ & 0.383 & $1.02(0.99,1.05)$ & 0.189 \\
\hline
\end{tabular}

All model $P<0.001$

${ }^{\text {a }}$ Model $X^{2}=188.82$;

${ }^{\mathrm{b}}$ Model $X^{2}=39.29$

${ }^{\mathrm{c}}$ Model $X^{2}=156.72$

sample, females or males; however, a violent conviction prior to the study period of 2007/2008 made violent recidivism more likely. Examining the gender split, this finding appears to relate to the males but not the females in the study. It therefore appears that a first violent offence does not necessarily mean that another will be committed. Rather, it is a repeated pattern of violence that makes further violence more likely. Both Indigenous males and females were observed to have a higher risk of further violence.

Table 11 displays the results for general recidivism. Individuals convicted of a violent offence in the $2007 / 2008$ study period were less likely to be reconvicted for a non-violent offence. This finding held for both the males and females in the study. Indigenous status was again a strong predictor of reoffending, regardless of gender.

Few notable gender differences were observed in relation to both violent and nonviolent reoffending. Past imprisonment was a predictor of both kinds of reoffending for the males but not the females in the sample, but as only 36 females had been previously imprisoned, the predictive validity of this variable for the females is perhaps doubtful. Prior offending was a strong predictor of both violent and non-violent recidivism for all individuals in the study. One other notable predictor was remoteness, with individuals living in more remote areas less likely to reoffend both violently and non-violently (but, note that this variable was unrelated to violent reoffending for the females). 
Table 11 Predictors of general recidivism, full sample, females and males

\begin{tabular}{|c|c|c|c|c|c|c|}
\hline & \multicolumn{6}{|l|}{ General recidivism } \\
\hline & \multicolumn{2}{|l|}{ Full sample ${ }^{\mathrm{a}}$} & \multicolumn{2}{|l|}{ Females $^{\mathrm{b}}$} & \multicolumn{2}{|l|}{ Males $^{\mathrm{c}}$} \\
\hline & $H$ & $P$ & $H$ & $P$ & $H$ & $P$ \\
\hline Violent offence & $0.75(0.71,0.82)$ & 0.001 & $0.82(0.68,1.00)$ & 0.046 & $0.76(0.70,0.82)$ & 0.000 \\
\hline Indigenous status & $1.60(1.47,1.66)$ & 0.001 & $1.80(1.54,2.10)$ & 0.000 & $1.52(1.42,1.63)$ & 0.000 \\
\hline Gender & $1.60(1.45,1.70)$ & 0.001 & & & & \\
\hline Age at conviction & $0.98(0.88,0.94)$ & 0.001 & $0.86(0.78,0.94)$ & 0.001 & $0.92(0.89,1.63)$ & 0.000 \\
\hline Age at first offence & $0.96(1.00,1.06)$ & 0.066 & $1.09(0.99,1.19)$ & 0.072 & $1.02(0.99,1.05)$ & 0.234 \\
\hline Socio-economic disadvantage & $0.99(0.96,1.02)$ & 0.455 & $1.03(0.96,1.10)$ & 0.424 & $0.98(0.95 .1 .01)$ & 0.224 \\
\hline Remoteness & $0.93(0.91,0.97)$ & 0.001 & $0.89(0.83,0.96)$ & 0.002 & $0.95(0.92,0.98)$ & 0.001 \\
\hline Prior offences & $1.14(1.19,1.28)$ & 0.001 & $1.35(1.21,1.50)$ & 0.000 & $1.22(1.17,1.27)$ & 0.000 \\
\hline Prior prison & $1.41(1.09,1.37)$ & 0.001 & $0.78(0.48,1.27)$ & 0.319 & $1.27(1.13,1.43)$ & 0.000 \\
\hline Prior suspended sentence & $1.05(0.87,1.12)$ & 0.818 & $1.50(0.93,2.42)$ & 0.097 & $0.96(0.84,1.10)$ & 0.586 \\
\hline Prior violence & $1.02(0.87,1.01)$ & 0.105 & $0.94(0.76,1.17)$ & 0.592 & $0.93(0.86,1.01)$ & 0.095 \\
\hline Prior breach of justice order & $1.27(1.03,1.25)$ & 0.008 & $1.23(0.96,1.58)$ & 0.109 & $1.12(1.01,1.24)$ & 0.027 \\
\hline Prior juvenile contact & $1.29(1.08,1.27)$ & 0.001 & $1.20(0.97,1.49)$ & 0.091 & $1.17(1.07,1.28)$ & 0.000 \\
\hline Counts & $0.97(0.95,1.01)$ & 0.124 & $0.96(0.84,1.09)$ & 0.488 & $0.98(0.95,1.01)$ & 0.134 \\
\hline Concurrent offences & $1.03(1.02,1.04)$ & 0.001 & $1.04(1.00,1.07)$ & 0.053 & $1.03(1.02,1.04)$ & 0.000 \\
\hline
\end{tabular}

All model $P<0.001$

${ }^{\text {a }}$ Model $X^{2}=1263.50$

${ }^{\mathrm{b}}$ Model $X^{2}=194.84$

${ }^{\mathrm{c}}$ Model $X^{2}=924.78$

\section{Discussion}

This study aimed to explore the characteristics of juvenile offenders convicted of a serious violent offence in the NSW Children's Court between 2007 and 2008 and to determine the extent to which a conviction for such an offence made the commission of further violence more likely. A further aim was to determine how intersections between sex and Indigenous status impacted on these relationships. The findings can be summarised as follows. Overall rates of serious violent offending and reoffending were low. Few differences were observed between individuals convicted of a violent and non-violent offence in the study period. If anything, the violent offenders were found to have a less serious criminal history profile. A small group of offenders with three convictions for violent offences were likewise found to have few differences from a comparison group of individuals convicted of series of non-violent offences. Finally, a violent conviction did not make a further violent offence more likely and made a further non-violent offence less likely. Violence prior to the study period was, however, a robust predictor of violent reoffending.

The study of criminal careers has focussed empirical attention on a number of different dimensions of offending behaviour since its inception [5, 13, 42]. One such 
dimension is the type of offences committed by individuals over the course of their offending careers or, more specifically, the extent to which individuals specialise in certain crimes or offend more generally. Overall, findings from this literature indicate that serious violent offending is a characteristic of frequent and chronic offenders. The longer a criminal career progresses, the more likely violence becomes. While the results of the current study are consistent with these conclusions, they also suggest that violence can also be an isolated incidence, perhaps contextually determined, and not necessarily involving individuals embedded in an offending career. For instance, offenders convicted of a violent offence took considerably longer to reoffend, both violently and non-violently. They were also less likely to reoffend non-violently. Instead, what seems indicative of a more serious criminal career was violence that occurred in the context of more extensive offending. Evidence for this comes from the multivariate recidivism models, where a violent offence committed prior to the index conviction in the 2007/2008 study period increased the likelihood of further violence considerably. A great deal of juvenile violence can be conceptualised as impulsive and contextually determined $[10,30]$. It is possible that some of the violent offences observed in the 2007/2008 study period were consistent with this description and might best be treated as isolated incidents by relevant justice authorities. Repeated violence, by contrast, seems a matter of greater concern.

Turning to the examination of intersections between sex and Indigenous status, no evidence of violent specialisation across these categories was observed. There was strong evidence, as in the study of Broidy et al. [9], to suggest that the Indigenous males could be considered chronic and frequent offenders. They had considerably more prior offences, were more likely to have been imprisoned, were more likely to reoffend both violently and non-violently and took a considerably shorter period to reoffend. In most respects, the Indigenous females lay somewhere between the Indigenous and nonIndigenous males. The exceptions to this were age at first conviction, which was similar to the Indigenous males, and future assault convictions, where they were over-represented. In fact, nearly a quarter of all the Indigenous females in the study were reconvicted of an assault charge.

Both the male and female Indigenous offenders were also found to be more likely to be reconvicted of a serious violent offence. While it is probable that the Indigenous over-representation among the offenders convicted of a serious violent offence relates to their more extensive and chronic criminal careers (particularly so in the case of the Indigenous males), it is also true that high levels of Indigenous violence remain a matter of pressing concern for researchers and policy makers. Theorists of Indigenous violence have alternatively argued that this behaviour is a culturally ingrained feature of Indigenous life [e.g. 50], a defiant response to White authority [12], the inevitable result of colonialism's destruction of Indigenous culture [11] or a reaction to strain [1]. Weatherburn recently reviewed these different accounts and concluded that none provided a satisfactory account of Indigenous violence, in part because they lacked strong empirical support and in part because none could explain both its intra- and inter- communal nature [54]. However, while alcohol and other substance misuse remains a strong predictor of Indigenous violence, there is also evidence to suggest the existence of culturally specific risk factors for Indigenous violence. These include the intergenerational trauma cased by the forced removal of children from Indigenous families, the strength of cultural and community bonds experienced by the individual 
and prior exposure to family violence $[21,46,56]$. In any event, the serious and violent nature of Indigenous offending careers should be a matter of continuing concern for all Australians.

\section{Limitations}

While the major aim of this study was to explore patterns of versatility and specialisation by juvenile offenders in Australia, limitations of the current dataset make it difficult to draw firm conclusions in this regard. Much of the best evidence for the life course developmental perspective has been derived from birth cohort studies. The advantage of these datasets is that they allow the examination of the longitudinal developmental of entire criminal careers. In addition, many of the best studies contain a rich variety of psychological, contextual and demographic measures. The current study by contrast utilised an administrative dataset containing a cross-sectional snapshot of the offending careers of the individuals involved. Its ability to test theories about the development of crime across the lifespan is therefore limited. A further characteristic of many of the great longitudinal studies of offending behaviour is inclusion of both self-reports of offending behaviour as well as official records. Researchers restricted to the use of official records might take some comfort from the findings of Huizinga and Elliott [28]; however, it is clear that the inclusion of both types of offending information is a considerable methodological strength that is lacking from the current study.

The current study can also say little about either the aetiology or nature of violent offending. Some gender and cultural differences were observed; however, more thorough-going investigations of these differences are required. In particular, a qualitative investigation of the different pathways to violence experienced by males, females and Indigenous Australians would be of the highest interest. More generally, the current study's conclusions could be strengthened by use of a more complete longitudinal record of juvenile offenders' careers comprising all offences committed by the individuals concerned over a more extensive study period extending into adulthood.

\section{Conclusion}

The current study was conducted in the context of a wider public debate in NSW about violent offending. This debate was triggered by the tragic death of Thomas Kelly on an inner-city Sydney street following an assault. ${ }^{7}$ Evidence from the life course developmental perspective shows violence to be a relatively rare component of long-term criminal careers and casts doubt on the existence of an exclusively violent offender. The current study's findings were largely consistent with the findings of life course criminology in this regard. Violent offending is a relatively rare phenomenon, and it appears that the commission of even the most serious violent offences does not inevitably lead

\footnotetext{
${ }^{7}$ See, for example, Swan (2014). 'Tony Abbott calls for states to get tougher on drunken violence', 9 January, 2014, Sydney Morning Herald: http://www.smh.com.au/federal-politics/political-news/tony-abbott-calls-forstates-to-get-tougher-on-drunken-violence-20140109-30jvp.html\#ixzz2qKE7D4qV
} 
to further violent offending. Of greater concern is a pattern of violence emerging as part of a long-term criminal career.

The findings of the current study should be of considerable interest to policy makers in Australia. They provide little justification for more punitive responses to violence, at least where it is the first time that the offender is charged with a violent offence. In these cases, the individual is no more likely to reoffend violently than a non-violent offender and, in fact, is likely to take longer to reoffend. A more compelling case for a punitive response could be made for repeat violent offenders, who may well be candidates for incapacitation or better still specialised therapeutic interventions [6]. However, it is important to remember that these individuals comprise only a small minority of juvenile offenders in NSW.

While violence remains such a salient feature of human behaviour, it is natural that it will continue to be a source of concern for both members of the public as well as policy makers. It is important that these debates are based on sound evidence. In this spirit, the current paper has examined violent offending by juveniles in NSW, Australia. Some evidence was observed to indicate the existence of a group of chronic offenders who also offend violently. Further research should be conducted in an effort to better identify these individuals. For the most part, however, the current results suggest that violent offending can be an isolated incident, and this is a finding that should be taken into consideration when policy responses to violence are formulated.

Acknowledgments I thank the NSW Bureau of Crime Statistics and Research for providing the data used in this study. The opinions here do not necessarily reflect the view of this organisation or its officers.

\section{References}

1. Agnew, R. (1992). Foundation for a general strain theory of crime and delinquency. Criminology, 30(1), 47-88.

2. Australian Bureau of Statistics (2001). Socio-economic indexes for areas. Canberra: Australian Bureau of Statistics.

3. Australian Bureau of Statistics. (2008). Australian Standard Offence Classification (ASOC). Canberra: Australian Bureau of Statistics.

4. Blokland, A. A. J., Nagin, D., \& Nieuwbeerta, P. (2005). Life span offending trajectories of a Dutch conviction cohort. Criminology, 43(4), 919-954. doi:10.1111/j.1745-9125.2005.00029.x.

5. Blumstein, A., Cohen, J., Roth, J. A., \& Visher, C. A. (1986). Criminal careers and "career criminals" (Vol. 1). Washington, D.C: National Academy Press.

6. Borduin, C. M., Mann, B., Cone, L., Henggeler, S., Fucci, B., Blaske, D., et al. (1995). Multisystemic treatment of serious juvenile offenders: long-term prevention of criminality and violence. Journal of Consulting \& Clinical Psychology, 63(4), 569-578. doi:10.1037/0022-006X.63.4.569.

7. Brame, R., Mazerolle, P., \& Piquero, A. R. (2010). Criminal career progression among serious youthful offenders in Australia. Journal of Criminal Justice, 38(4), 340-347. doi:10.1016/j.jcrimjus.2010.04.001.

8. Brame, R., Mulvey, E. P., \& Piquero, A. R. (2001). On the development of different kinds of criminal activity. Sociological Methods \& Research, 29(3), 319-341. doi:10.1177/0049124101029003003.

9. Broidy, L. M., Stewart, A., Thompson, C., Chrzanowski, A., Allard, T., \& Dennison, S. (2015). Life course offending pathways across gender and race/ethnicity. Journal of Developmental and Life-Course Criminology, 1(2), 118-149. doi:10.1007/s40865-015-0008-z.

10. Cauffman, E., Steinberg, L., \& Piquero, A. R. (2005). Psychological, neuropsychological and physiological correlates of serious antisocial behavior in adolescence: the role of self-control. Criminology, 43(1), 133-176. doi:10.1111/j.0011-1348.2005.00005.x. 
11. Commonwealth of Australia. (1991). Royal commission into aboriginal deaths in custody. Canberra: Commonwealth of Australia.

12. Cunneen, C. (2001). Conflict, politics and crime: aboriginal communities and the police (conflict, politics and crime: aboriginal communities and the police). Crows Nest: Allen and Unwin.

13. DeLisi, M., \& Piquero, A. R. (2011). New frontiers in criminal careers research, 2000-2011: a state-ofthe-art review. Journal of Criminal Justice, 39(4), 289-301. doi:10.1016/j.jcrimjus.2011.05.001.

14. Elliott, D. S., Huizinga, D., \& Menard, S. (1989). Multiple problem youth: delinquency, substance use, and mental health problems. New York: Springer-Verlag.

15. Elliott, D. S., Huizinga, D., \& Morse, B. (1986). Self-reported violent offending: a descriptive analysis of juvenile violent offenders and their offending careers. Journal of Interpersonal Violence, 1(4), 472-514. doi:10.1177/088626086001004006.

16. Ezell, M. E. (2007). Examining the overall and offense-specific criminal career lengths of a sample of serious offenders. Crime \& Delinquency, 53(1), 3-37. doi:10.1177/0011128706294437.

17. Farrington, D. P. (1995). The development of offending and antisocial behaviour from childhood: key findings of the Cambridge study in delinquent development. Journal of Child Psychology and Psychiatry, 360(6), 929-964.

18. Farrington, D. P. (2003). Developmental and life-course criminology: key theoretical and empirical issues. Criminology, 41(2), 221-225. doi:10.1111/j.1745-9125.2003.tb00987.x.

19. Farrington, D. P., Snyder, H. N., \& Finnegan, T. A. (1988). Specialization in juvenile court careers. Criminology, 26(3), 461-488.

20. Ferrante, A. M. (2013). Assessing gender and ethnic differences in developmental trajectories of offending. Australian \& New Zealand Journal of Criminology, 46(3), 379-402. doi:10.1177/ 0004865813490948.

21. Ferrante, A. M. (2013). Assessing the influence of "standard" and "culturally specific" risk factors on the prevalence and frequency of offending: the case of Indigenous Australians. Race and Justice, 3(1), 58-82. doi: $10.1177 / 2153368712462410$.

22. Field, A. (2013). Discovering statistics using IBM SPSS statistics. London: Sage.

23. Fitzgerald, R., Mazerolle, P., Piquero, A. R., \& Ansara, D. L. (2011). Exploring sex differences among sentenced juvenile offenders in Australia. Justice Quarterly, 29(3), 420-447. doi:10.1080/07418825.2011. 565361.

24. Glueck, S., \& Glueck, E. (1950). Unraveling juvenile delinquency. New York: Commonwealth Fund.

25. Guerette, R. T., Stenius, V. M., \& McGloin, J. M. (2005). Understanding offense specialization and versatility: a reapplication of the rational choice perspective. Journal of Criminal Justice, 33(1), 77-87.

26. Harris, D. A., Smallbone, S., Dennison, S., \& Knight, R. A. (2009). Specialization and versatility in sexual offenders referred for civil commitment. Journal of Criminal Justice, 37(1), 37-44.

27. Hua, J., \& Fitzgerald, J. (2006). Matching court records to measure reoffending. Crime and justice bulletin: contemporary issues in crime and justice (Vol. 95). Sydney: NSW Bureau of Crime Statistics and Research.

28. Huizinga, D., \& Elliott, D. S. (1986). Reassessing the reliability and validity of self-report delinquency measures. Journal of Quantitative Criminology, 2(4), 293.

29. Kempf, K. (1986). Offense specialization: does it exist? In D. Cornish \& R. Clarke (Eds.), The reasoning criminal: rational choice perspectives on offending (pp. 186-201). New York: Springer.

30. Krug, E. G., Mercy, J. A., Dahlberg, L. L., \& Zwi, A. B. (2002). The world report on violence and health. The Lancet, 360(9339), 1083-1088.

31. Loeber, R., \& Farrington, D. P. (Eds) (1998). Serious \& violent juvenile offenders: risk factors and successful interventions. Thousand Oaks: Sage.

32. Loeber, R., Farrington, D. P., \& Waschbusch, D. A. (1998). Serious and violent juvenile offenders. In R. Loeber \& D. P. Farrington (Eds), Risk factors and successful interventions (pp. 13-29) xxv, 507pp.

33. Lumley, T., Diehr, P., Emerson, S., \& Chen, L. (2002). The importance of the normality assumption in large public health data sets. Annual review of public health, 23(1), 151-169.

34. Mazerolle, P., Brame, R., Paternoster, R., Piquero, A. R., \& Dean, C. (2000). Onset age, persistence and offending versatility: comparisons across gender. Criminology, 38(4), 1143-1172. doi:10.1111/j.17459125.2000.tb01417.x.

35. Mazerolle, P., Piquero, A. R., \& Brame, R. (2010). Violent onset offenders: do initial experiences shape criminal career dimensions? International Criminal Justice Review, 20(2), 132-146. doi:10.1177/ 1057567710368361.

36. McGloin, J. M., Sullivan, C. J., Piquero, A. R., \& Pratt, T. C. (2007). Local life circumstances and offending specialization/versatility comparing opportunity and propensity models. Journal of Research in Crime and Delinquency, 44(3), 321-346. 
37. Moffitt, T. E. (1993). Adolescence-limited and life-course-persistent antisocial behaviour: a developmental taxonomy. Psychological Review, 100(4), 674-701.

38. Monahan, K. C., \& Piquero, A. R. (2009). Investigating the longitudinal relation between offending frequency and offending variety. Criminal Justice and Behavior, 36(7), 653-673. doi:10.1177/ 0093854809335527.

39. NSW Department of Police and Justice. (2014). 2013-14 Annual Report. Sydney: NSW Department of Police and Justice.

40. Olver, M. E., Stockdale, K. C., \& Wormith, J. S. (2009). Risk assessment with young offenders: a metaanalysis of three assessment measures. Criminal Justice and Behavior, 36(4), 329-353. doi:10.1177/ 0093854809331457.

41. Piper, E. (1985). Violent recidivism and chronicity in the 1958 Philadelphia cohort. Journal of Quantitative Criminology, 1(4), 319-344. doi:10.1007/BF01064185.

42. Piquero, A. R., Farrington, D. P., \& Blumstein, A. (2003). The criminal career paradigm. In M. Tonry (Ed.), Crime and justice: an annual review of research (Vol. 30, pp. 359-506). Chicago: University of Chicago.

43. Piquero, A. R., Jennings, W. G., \& Barnes, J. C. (2012). Violence in criminal careers: a review of the literature from a developmental life-course perspective. Aggression and Violent Behavior, 17(3), 171-179. doi:10.1016/j.avb.2012.02.008.

44. Rebecca Block, C., Blokland, A. A. J., van der Werff, C., van Os, R., \& Nieuwbeerta, P. (2010). Long-term patterns of offending in women. Feminist Criminology, 5(1), 73-107. doi:10.1177/1557085109356520.

45. Sampson, R. J., \& Laub, J. H. (2003). Life-course desisters? Trajectories of crime among delinquent boys followed to age 70. Criminology, 41(3), 555-592.

46. Shepherd, S. M. (2014). Finding color in conformity: a commentary on culturally specific risk factors for violence in Australia. International Journal of Offender Therapy and Comparative Criminology. doi:10. 1177/0306624x14540492.

47. Snyder, H. N. (1998). Serious, violent, and chronic juvenile offenders — an assessment of the extent of and trends in officially recognised serious criminal behavior in a delinquent population. In R. Loeber \& D. P. Farrington (Eds.), Serious \& violent juvenile offenders: risk factors and successful interventions (pp. 428486). Thousand Oaks: Sage.

48. StataCorp. (2009). Stata 11 base reference manual. College Station: Stata Press.

49. StataCorp. (2009). Stata Statistical Software: release 11. College Station: Statacorp LP.

50. Sutton, P. (2001). The politics of suffering: Indigenous policy in Australia since the 1970s. Anthropological Forum, 11(2), 125-173.

51. Tolan, P. H., \& Gorman-Smith, D. (1998). Development of serious and violent offending careers. In R. Loeber \& D. Farrington (Eds.), Serious \& violent juvenile offenders: risk factors and successful interventions (pp. 68-85). Thousand Oaks: Sage.

52. Tracy, P. E., Wolfgang, M. E., \& Figlio, R. M. (1990). Delinquency careers in two birth cohorts. New York: Plenum Press.

53. Tzoumakis, S., Lussier, P., Blanc, M. L., \& Davies, G. (2013). Onset, offending trajectories, and crime specialization in violence. Youth Violence and Juvenile Justice, 11(2), 143-164. doi:10.1177/ 1541204012458440 .

54. Weatherburn, D. (2014). Arresting incarceration: pathways out of Indigenous imprisonment. Canberra: Aboriginal Studies Press.

55. Weatherburn, D., Lind, B., Hua, J. (2003). Contact with the New South Wales court and prison systems: the influence of age, Indigenous status and gender. Crime and Justice Bulletin: contemporary issues in crime and justice (Vol. No. 78). Sydney: NSW Bureau of Crime Statistics and Research.

56. Weatherburn, D., Snowball, L., Hunter, B. (2006). The economic and social factors underpinning Indigenous contact with the justice system: results from the 2002 NATSISS survey. Crime and justice bulletin: contemporary issues in crime and justice; no. 104.

57. Wolfgang, M. E., Figlio, R. M., \& Sellin, T. (1972). Delinquency in a birth cohort. Chicago: University of Chicago Press. 